\title{
Abnormalitas Morfologi Spermatozoa Ayam Nunukan Asal Ejakulat
}

\author{
Fikri Ardhani ${ }^{1}$, Julinda R. Manullang ${ }^{2}$, dan Bryta Mbincar Boangmanalu ${ }^{3}$ \\ 1,2,3 Jurusan Peternakan Fakultas Pertanian, Universitas Mulawarman, Kampus \\ Gunung Kelua Jl. Pasir Belengkong Po.Box. 1040 \\ 1email : fikri_ardhani@faperta.unmul.ac.id
}

\begin{abstract}
Nunukan chickens, Indonesian germplasm, spread out the northern and eastern part of Kalimantan. The high morphological abnormality percentage of spermatozoa would decrease the value of fertility. The research aims to identify abnormalities in the shape and to develop abnormality identification material through painting by using eosin nigrosin. Ten nunukan roosters, above one year old with weight, 2-2,5 kg, were collect its semen with dorsal massage method. The make of swab preparat were stained by using a solution of eosin nigrosin. The spermatozoa abnormality percentage was counted and the shape abnormality was observed by using microscope. The percentage of abnormality spermatozoa of nunukan rooster on staining by eosin nigrosin was 13,01 $\pm 2,16 \%$; the abnormality is generally dominated at the tail part where by eosin nigrosin was $8,52 \pm 1,89 \%$. The abnormality shapes of the head were dominated by the head without tail, round head, and the swelled head. The abnormality shapes of the middle part were dominated by the folding of middle, section roundling, and broken. The abnormality shapes of the tail part were dominated by the round tail, bent tail, and broken tail. The use of eosin nigrosin staining is effective for sperm morphology evaluation of nunukan chiken Spermatozoa because from than eosin microscopic observation; result the good one contrast between the cell and the background.
\end{abstract}

Keywords: nunukan rooster, abnormality spermatozoa, eosin nigrosine

\begin{abstract}
ABSTRAK
Ayam nunukan merupakan plasma nutfah Indonesia yang berkembang di wilayah Kalimantan terutama bagian Utara dan Timur. Tingginya persentase abnormalitas morfologi spermatozoa akan menurunkan nilai fertilitas. Penelitian ini bertujuan untuk mengidentifikasi abnormalitas bentuk dan akan dikembangkan bahan identifikasi abnormalitas melalui pengecatan menggunakan kombinasi eosin nigrosin. Sepuluh ekor ayam nunukan jantan diatas satu tahun dengan bobot 2-2,5 kg dikoleksi semennya dengan metode massage atau pengurutan bagian punggung (dorsal) ayam jantan. Pembuatan preparat ulas dilakukan dengan menggunakan larutan kombinasi eosin nigrosin. Persentase abnormalitas spermatozoa dihitung dan identifikasi bentuk abnormalitas diamati dengan menggunakan mikroskop. Persentase abnormalitas spermatozoa ayam nunukan sebesar $13,01 \pm 2,16 \%$; abnormalitas umumnya didominasi pada bagian ekor $8,52 \pm 1,89 \%$. Bentuk abnormalitas bagian kepala didominasi oleh kepala tanpa ekor, kepala melingkar, dan kepala membengkak. Bentuk abnormalitas bagian tengah didominasi oleh bagian tengah melipat, melingkar dan patah. Bentuk abnormalitas bagian ekor didominasi oleh bagian ekor melingkar, membengkok, dan patah. Penggunaan pengecatan eosin nigrosin efektif untuk pengamatan evaluasi morfologi spermatozoa ayam nunukan karena berdasar pada pengamatan mikroskopis menghasilkan kontras antara sel dan background yang baik.
\end{abstract}

Kata kunci : ayam nunukan, abnormalitas spermatozoa, eosin nigrosin

Pendahuluan

Ayam buras merupakan sumber genetik ternak yang perlu di lestarikan, masih alami dan belum banyak mengalami perbaikan mutu genetis. Beberapa daerah ayam buras dikembangkan masyarakat sehingga memiliki karakteristik yang relatif homogen, baik bentuk tubuh maupun warna bulu (Johari dkk, 2009). Ayam nunukan merupakan salah 
satu plasma nutfah Indonesia yang belum banyak berkembang di wilayah Kalimantan terutama bagian Utara (Sartika dkk, 2006).

Sebagai upaya meningkatkan produktifitas ternak di masa yang akan datang melalui teknologi reproduksi seperti inseminasi buatan (IB) dan in vitro fertilisasi (IVF) perlu diketahui terlebih dahulu tentang karakteristik unsur perkawinan hewan tersebut, baik dari sisi betina maupun pejantan. Dalam proses fertilisasi kontribusi seekor pejantan hanya terbatas pada sel sperma (spermatozoa). Tingkat fertilsasi ditinjau dari aspek pejantan berupa sperma ditentukan oleh empat faktor yaitu pergerakan daya gerak (motilitas) kemampuan hidup (viabilitas) dan keutuhan DNA (deoxyribose-nucleic acid) serta morfologi dari sperma (Morell dkk., 2009). Ardhani (2014) telah mengkarakterisasi kualitas semen dan spermatozoa ayam nunukan dan menyatakan bahwa secara morfologi spermatozoa normal ayam nunukan berkisar $80,25 \%$. Hal ini menunjukkan bahwa ada spermatozoa yang memiliki abnormalitas morfologi yang pada akhirnya akan menurunkan nilai fertilitas. Penelitian ini dimaksudkan untuk mengetahui bentuk dan jenis abnormalitas spermatozoa untuk mengidentifikasi abnormalitas bentuk dan akan dikembangkan bahan identifikasi abnormalitas melalui pengecatan eosin nigrosin.

\section{Metode Penelitian}

\section{Waktu dan Tempat}

Penelitian ini dilaksanakan pada Juni-Agustus 2015 di Laboratorium Produksi dan Teknologi Peternakan Jurusan Peternakan Fakultas Pertanian Universitas Mulawarman, Samarinda.

\section{Bahan dan Alat}

Bahan yang digunakan dalam penelitian ini adalah 10 ekor ayam nunukan jantan berumur diatas satu tahun dengan bobot badan 2-2,5 kg. Ayam tersebut di kandangkan Teaching Farm Dinas Perikanan dan Peternakan Kota Samarinda. Ayam dipelihara pada kandang individu ukuran $1 \times 2 \mathrm{~m}^{2}$ dengan pencahayaan \pm 12 jam per hari. Bahan lainya antara lain semen segar ayam Nunukan, eosin, eosin nigrosin dan $\mathrm{NaCl} 0,9 \%$.

Alat yang digunakan dalam penelitian ini antara lain: mikroskop OptiLab, kamera, monitor, collection tube, pipet tetes, kertas $\mathrm{pH}$, objek glass, cover glass, tabung reaksi, kamera digital.

Umur ayam dalam penelitian ini adalah umur diatas satu tahun dengan bobot badan 2-2,5 kg. Ayam dipelihara pada kandang individu ukuran $1 \times 2 \mathrm{~m}^{2}$ dengan pendahayaaan \pm 12 jam per hari. Suhu dalam kandang penelitian adalah $24-28^{\circ} \mathrm{C}$.

Tingkat ransangan ayam dalam penelitian ini adalah tingkat ransangannya tinggi Teknik pengurutan atau massage adalah dengan mengusap punggung ayam jantan sampai pangkal ekor dengan jemari tangan kanan kemudian diteruskan naik sampai keekor 
telapak tangan kolektor membentuk sudut $30-40^{\circ}$ dari punggung ayam jantan.

ISSN 2354-7251 (print)

Frekuensi ejakulasi adalah dilakukan setiap dua hari sehari dan dilakukan dengan metode massage atau pengurutan bagian punggung (dorsal) ayam jantan. Pemberian minum secara ad libitum dan pemberian pakan setiap dua kali dalam sehari sebanyak 100$150 \mathrm{~g} /$ hari menggunakan pakan komersial. Kondisi ternak dalam penelitian ini adalah ternaknya harus sehat dan tidak ada sakit supaya pada saat penampungan semen hasil ya bagus.

\section{Koleksi Semen}

Pengoleksian semen segar dilakukan setiap dua hari sekali dan dilakukan dengan metode massage atau pengurutan bagian punggung (dorsal) ayam jantan. Bagian sekitar bibir dan kloaka dibersihkan terlebih dahulu dengan tissue yang telah dibasahi $\mathrm{NaCl}$, apabila bulu di sekitas kloaka cukup banyak maka bulu tersebut dipotong dengan menggunakan gunting. Teknik pengurutan atau massage adalah dengan mengusap punggung ayam jantan sampai pangkal ekor dengan jemari tangan kanan kemudian diteruskan naik sampai ke ekornya, telapak tangan kolektor membentuk sudut $30-40^{\circ}$ dari punggung ayam jantan.

Perabaan harus halus dan tepat agar ayam terangsang ditunjukkan dengan ekor terangkat, kaki agak meregang, kloaka membuka dan terlihat sepasang papilla (phallus nonprotudens) menonjol. Tangan kanan secara cepat memenggam dan sedikit mengangkat pangkal ekor, jari tengah dan ibu jari menekan dasar kloaka dan tetap menahan agar kedua papilla tetap menonjol. Metode tersebut dilakukan dengan tekanan tertentu sampai keluar cairan bening (transudat kloaka) yang diikuti oleh cairan kental berwarna putih susu. Transundat kloaka harus dihindari karena jika tercampur dengan semen, maka akan menyebabkan semen mengalami penggumpalan (aglutinasi) (Supriatna, 2000). Cairan kental (semen) segera ditampung dengan tabung penampung berukuran $1,5 \mathrm{~mL}$ yang ditutup dengan aluminium foil.

\section{Penilaian makroskopis}

Penilaian makroskopis dilakukan dengan pengamatan volume dilihat dari skala yang ditunjukkan pada spuit, uji $\mathrm{pH}$ menggunakan kertas $\mathrm{pH}$ skala 6.4-8.0 pengamatan warna dan bau semen.

\section{Pengecatan}

Pengambilan semen dari ayam penelitian setelah itu dilakukan pengecatan di laboratorium. Pembuatan preparat ulas dilakukan dengan menggunakan 3 kaca objek untuk tiap sampelnya. Semen segar dicampurkan dengan larutan Eosin, Eosin Nigrosin dengan perbandingan 1:50 pada kaca objek campuran semen tersebut diaduk hingga homogen dengan ujung gelas objek lainnya kemudian dibuat preparat ulas setipis mungkin pada ketiga gelas objek yang berbeda kemudian dikeringkan. 


\section{Pengamatan Abnormalitas}

Jumlah sperma yang diamati morfologinya dalam satu bidang pandang untuk tiap ulangan pengamatan abnormalitas menggunakan makroskopis dengan perbesaran objektif 40x persentasi abnormalitas dihitung berdasarkan dengan rumus:

$$
\text { Persentasi }=\frac{\text { Jumlah spermatozoa abnormalitas }}{\text { Jumlah spermatozoa keseluruhan }} \times 100 \%
$$

Karakteristik kerusakan morfologi yang diamati mengacu kepada Alkan dkk (2002).

\section{Hasil dan Pembahasan}

Volume semen ayam nunukan yang diperoleh sebesar $0,40 \pm 0,13 \mathrm{~mL}$. Volume semen ayam nunukan hasil penelitian ini lebih tinggi dari laporan Ardhani (2014) sebesar 0,21 $\pm 0,15 \mathrm{~mL}$. Volume semen ayam umumnya berkisar antara 0,3-1,5 mL (Tholihere, 1993). Beberapa faktor yang dapat mempengaruhi volume semen saat koleksi semen adalah umur, tingkat rangsangan, frekuensi ejakulasi, kualitas pakan yang diberikan, serta kondisi ternak itu sendiri (Jonhson dkk., 2000; Toelihere, 1993).

Tabel 1. Kualitas semen segar ayam nunukan

\begin{tabular}{cc}
\hline Karakteristik & Rata-rata \\
\hline Volume ejakulat(mL) & $0,40 \pm 0,13$ \\
Warna & Putih susu \\
Bau & Spermin \\
$\mathrm{pH}$ & $7,34 \pm 0,15$ \\
\hline
\end{tabular}

Bangsa ayam baru mencapai dewasa kelamin pada umur 24-26 minggu dan individu muda dalam satu spesies menghasilkan volume semen yang rendah (Toelihere, 1993). Umur jantan yang baik untuk di koleksi semennya adalah pada umur 1-1,5 tahun (48-72 minggu) dan umur jantan ayam lokal 40-80 minggu merupakan penghasil semen terbaik (Sastrodihardjo dan Resnawati, 2003). Umur ayam jantan yang digunakan dalam penelitian ini berkisar antara 48-96 minggu, sehingga tingkat produksi spermatozoa cukup optimum.

Hasil yang sudah diamati secara visual warna semen ayam nunukan yang didapat berwarna putih susu. Warna semen ayam dapat tercemar akibat tercampur dengan feses, atau darah.

Nilai pH semen yang didapat adalah $7,34 \pm 0,15$. Nilai ini lebih tinggi dari pada penelitian sebelumnya (Ardhani, 2014) dengan $\mathrm{pH} 7,20 \pm 0,10$, namun masih berada pada kisaran pH normal ayam yaitu 7,0-7,6 (Toelihere, 1993). Variasi dalam derajat keasaman disebabkan oleh suhu lingkungan sekitar kandang pemeliharaan (Mulyadi, 2007). Nilai pH semen juga dapat dipengaruhi oleh kontaminasi kuman dan banyaknya spermatozoa mati 
dalam semen akibat terlalu lama sehingga memicu terbentuknya ammonia (Ardhani, 2014).

Secara umum, variasi abnormalitas spermatozoa dapat disebabkan oleh beberapa faktor, seperti: genetik, tingkat stres yang berbeda, respon terhadap suhu lingkungan dan penyakit masing-masing individu (Barth dan Oko, 1989).

Abnormalitas bagian kepala memiliki potensi lebih rendah terkait keberhasilan fertilisasi (Barth dan Oko, 1989) karena kepala spermatozoa mengandung materi genetik yang akan diturunkan pada anak ayam sehingga abnormalitas bagian kepala sangat dihindari. Oleh karena itu, salah satu tindakan seleksi pada jantan ayam nunukan yang memiliki banyak abnormalitas pada bagian kepala adalah culling (afkir) atau dapat melakukan tindakan prevatif seperti perbaikan manajemen pakan dan mengurangi potensi stres selama masa pertumbuhan ayam nunukan.

Abnormalitas spermatozoa bagian ekor tergolong abnormalitas sekunder yang banyak terjadi setelah proses spermatogenesis dan faktor eksternal seperti syok akibat adaptasi perubahan lingkungan dan preparasi semen yang kurang hati-hati setelah koleksi seperti kemungkinan bercampurnya cairan eksudat atau ekreta. Bagian ekor spermatozoa berperan dalam pergerakan spermatozoa dalam proses pembuahan, sehingga secara tidak langsung mempengaruhi keberhasilan fertilisasi sel telur. Abnormalitas ini dapat diminimalisir dengan manajemen preparasi semen yang lebih baik seperti menghindarkan kotak langsung dengan matahari, prevarasi yang cepat dan tepat serta melakukan teknik koleksi secara rutin untuk melatih jantan ayam nunukan mengejakulasikan semen dengan teknik massage (Mulyadi, 2007).

Tabel 2. Abnormalitas spermatozoa ayam nunukan dengan pewarnaan eosin nigrosin (dalam persen)

\begin{tabular}{cc}
\hline Abnormalitas & Rata-rata \\
\hline Spermatozoa abnormal & $13,01 \pm 2,10$ \\
Abnormal kepala & $2,63 \pm 0,92$ \\
Abnormal tengah & $1,87 \pm 0,61$ \\
Abnormal ekor & $8,52 \pm 1,89$ \\
\hline
\end{tabular}

Berdasarkan variasi bentuk abnormalitas yang dihasilkan untuk seleksi ayam nunukan, jantan 4 dan 5 layak untuk dipertahankan karena total jumlah abnormalitas paling rendah, selain itu abnormalitas bagian kepala juga lebih rendah dibandingkan jantan lain, sebagai pembawa materi genetik yang diturunkan pada keturunanya sehingga penting untuk mempertahankan jantan dengan kepala spermatozoa normal yang baik. Berdasarkan penelitian Bakst (1987) fertilisasi unggas jantan dapat optimum apabila abnormalitas spermatozoanya kurang dari $10 \%$, namun perlu dilakukan penelitian lebih lanjut tentang pengaruh masing-masing bentuk abnormalitas terhadap fertilitas unggas jantan.

Persentase abnormalitas spermatozoa pada pewarnaan eosin nigrosin rata-rata ayam nunukan dalam penelitian ini adalah $13,01 \pm 2,10 \%$. Pada hasil pewarnaan dengan 
eosin nigrosin, sel spermatozoa dapat terlihat dengan jelas sehingga dapat banyak mengidentifikasikan bentuk kelainanya. Eosin merupakan zat warna yang mampu berpendar karena mengandung brom sehingga dapat mewarnai sitoplasma (Gunarso, 1989). Eosin nigrosin tidak mengandung chloramin yang dapat mengikis membrane sel. Menurut Arifiantini dkk. (2006) pengeringan preparat pewarnaan eosin nigrosin menggunakan meja pemanas menyebabkan pergeseran ukuran kepala sehingga terlihat lebih besar.

\section{Abnormalitas spermatozoa ayam nunukan dengan pewarnaan eosin nigrosin}

Abnormalitas bagian kepala pada penelitian ini secara keseluruhan paling tinggi ditemukan pada bentuk kepala spermatozoa tanpa ekor sejalan dengan hasil penelitian Mulyadi (2007) bahwa abnormalitas kepala tanpa ekor banyak ditemukan pada semen ayam arab, kedu dan pelung. Putusnya kepala dari ekor disebabkan oleh bagian tengah spermatozoa unggas yang sensitif terhadap pengaruh eksternal seperti rangsangan panas (Alkan dkk., 2002). Selain itu juga diduga disebabkan karena spermatozoa terlalu lama berada di epididimis sehingga menyebabkan banyak spermatozoa mati dan terjadi absorbsi bagian-bagian spermatozoa karena sebelumnya sampel jantan belum pernah dikoleksi semennya. Oleh karena itu perlu adanya manajemen koleksi semen secara rutin.

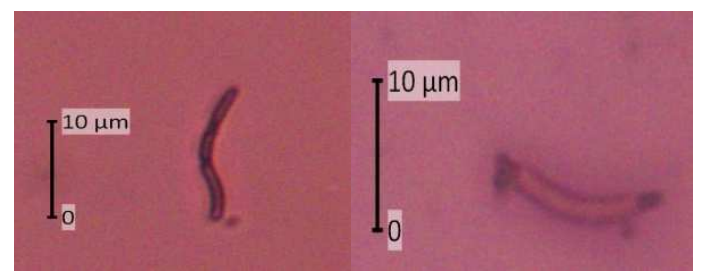

Gambar 1. Bentuk kepala tanpa ekor

Kepala melingkar pada bagian tengah maupun ujungnya sedangkan bentuk smaller/larger head atau ukuran kepala yang bervariasi. Menurut Barth dan Oko, (1989) pada mamalia umumnya abnormalitas pada bentuk ini di sebabkan oleh faktor genetik yang terjadi akibat defisiensi kromatin inti yang mengarah pada kehilangan atau kelebihan pembentukan kromosom. Kegagalan pemisahan kromosom pada proses pembelahan sel (spermatogenesis) yang dapat menyebabkan kelebihan kromosom inti dapat disebebkan oleh perubahan lingkungan seperti suhu lingkungan yang fluktuatif pada musim kemarau.

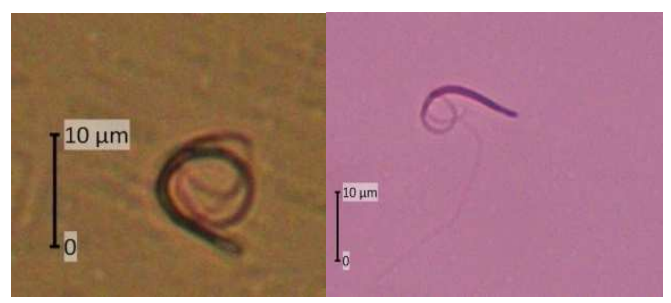

Gambar 2. Bentuk kepala melingkar atau ukuran kepala bervariasi 


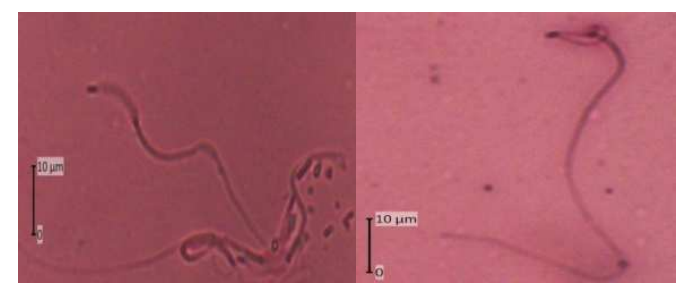

Gambar 3. Bentuk kepala membengkak

Kepala membengkak adalah bentuk kepala abnormal yang paling sedikit berbeda dengan dengan Alkan dkk. (2002) yang menemukan swelled head/ kepala membengkak dengan persentase paling banyak pada semen kalkun. Alkan dkk. (2002) menjelaskan bahwa kepala spermatozoa membengkak sesaat semen diejakulasikan yang diakibatkan peredaan tekanan osmosis dan suhu sehingga sulit untuk menentukan swelled head yang abnormal.

Kerusakan pada bagian kepala dan tengah sehigga pada bagian tengah terlihat melipat dan patah. Bentuk ini disebabkan karena sifat sensitive pada bagian tengah spermatozoa dan gerakan ekor. Dalam penelitian ini cukup banyak ditemukan dengan kondisi kepala melengkung membentuk siku.

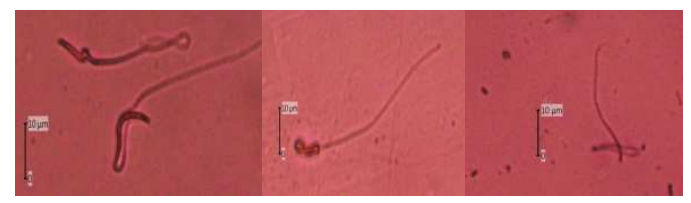

Gambar 4. Bentuk beragam kerusakan pada bagian tengah (melipat dan patah)

Bentuk abnormal pada bagian tengah hanya ditemukan pada bentuk melipat dan patah jenis abnormal ini sering terjadi karena proses yang abnormal selama ejakulasi yang dapat terjadi akibat teknik koleksi yang belum terbiasa dilakukan pada jantan syok dan stress pada kondisi tersebut mengingat bagian tengah sperematozoa adalah bagian yang sensitive oleh faktor eksternal (Alkan dkk. 2002).

Sejalan dengan hasil penelitian Mulyadi (2007) yang banyak menemukan abnormalitas dengan bentuk ekor melingkar (bending or knotting), ekor patah dan kepala tanpa ekor (head detachment) spermatozoa ayam arab. Tail detachment atau ekor tanpa kepala, bentuk ini juga disebabkan oleh faktor sekunder. Abnormalitas ini juga dapat terjadi secara primer akibat adanya gangguan selama spermatogenesis dimulai dengan bagian posterior kepala yang tidak terbentuk dengan sempurna sehingga menghasilkan ketidakstabilan pada daerah implantasi ekor. Kepala dan ekor hanya dihubungkan dengan membran sel, sehingga kemungkinan terpisahnya kepala dan ekor karena awal dari pergerakan sel dan perpindahan sisa sitoplasma (Barth dan Oko, 1989). 


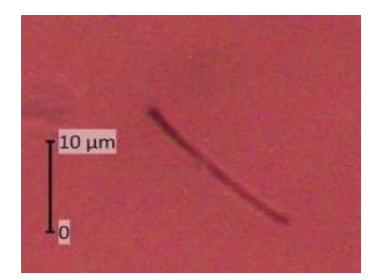

Gambar 5. Bentuk abnormalitas ekor tanpa kepala

Bentuk ekor patah seperti pada yang terlihat patah yang paling banyak ditemukan dibandingkan bentuk ekor abnormal lainya, sedangkan bentuk ekor melingkar ditemukan paling banyak kedua. Beberapa peneliti menyatakan bahwa kerusakan ekor spermatozoa unggas dalam semen terjadi akibat faktor eksternal dan mekanis sehingga abnormal pada ekor tergolong dalam jenis abnormalitas sekunder. Meskipun tidak memiliki resiko sebesar abnormalitas bagian kepala, abnormalitas bagian ekor juga perlu diminimalisir dengan perbaikan manajemen koleksi dan preservasi semen pasca ejakulasi.

Dalam penelitian ini adalah pewarnaan dengan eosin nigrosin lebih baik dan efektif dibandingkan dengan pewarnaan eosin. Pewarnaan eosin nigrosin lebih mudah untuk mendeteksi bentuk-bentuk abnormalitas sperma karna memberikan background sedangkan eosin tidak ada memberikan background. Hasil tersebut juga didukung dengan pengujian statistik pada taraf $5 \%$ menolak sehingga dapat dinyatakan bahwa pernyataan eosin nigrosin lebih baik dari pada pewarnaan eosin.

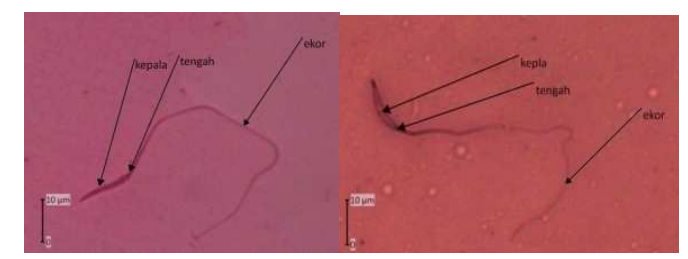

Gambar 6. Bentuk sermatozoa dengan pewarnaan eosin dan eosin nigrosin

Pengamatan yang dilakukan dengan menggunakan pewarnaan eosin umumnya hanya dapat menemukan kondisi abnormalitas pada bagian ekor sedangkan pada bagian kepala dan tengah pewarnaan tidak terlihat dan beberapa sampel menunjukkan kondisi kepala lisis sehingga sulit mengidentifikasi bentuk abnormalitasnya.

\section{Kesimpulan}

Persentase abnormal spermatozoa ayam nunukan rata-rata sebesar $13,01 \pm 2,16 \%$. Bentuk abnormalitas bagian kepala pada pewarnaan eosin didominasi oleh kepala tanpa ekor, kepala melingkar, dan kepala membengkak rata-rata sebesar $3,19 \pm 0,89 \%$. Bentuk abnormalitas bagian kepala pada pewarnaan eosin nigrosin didominasi oleh kepala tanpa ekor, kepala melingkar, dan kepala membengkak rata-rata sebesar $2,63 \pm 0,92 \%$. Bentuk 
abnormalitas bagian tengah pada pewarnaan eosin nigrosin didominasi oleh bagian tengah melipat, melingkar dan patah rata-rata sebesar $1,87 \pm 0,61 \%$. Bentuk abnormalitas bagian ekor pada pewarnaan eosin nigrosin didominasi oleh bagian ekor melingkar, membengkok, dan patah rata-rata sebesar $8,52 \pm 1,89 \%$.

Berdasarkan pengamatan secara visual, pengecatan sperma menggunakan bahan eosin nigrosin memberikan performans yang baik karena kombinasi bahan kedua bahan pengecatan ini memberikan efek kontras melalui perbedaan background dan objek sel sperma.

\section{Daftar Pustaka}

Alkan, S., A. Baran, O.B. ozdas, \& M. Evecen. (2002). Morfologi defects in turkey semen. J Vet Anim Sci. 26: 1087-1092.

Ardhani, F.(2014). Karakteristik Semen dan Spermatozoa ayam Nunukan. Penelitan Mandiri Faperta Universitas Mulawarman.

Arifiantini, R.I., T. Wresdiyati, \& E.F. Retnani. (2006). Pengujian morfologi spermatozoa sapi bali (Bos Sondaicus) menggunakan pewarnaan "Williams". J Indon Trop Anim Agric. 31(2):105-110.

Barth, A.D., \& R.J. Oko. (1989). Abnormal Morphology of Bovine spermatozoa. Lowa (US): lowa state University Pr.

Gunarso, W. (1989). Mikroteknik. Bogor (ID): Pusat antar Universitas IImu Hayati Institut Pertanian Bogor.

Johari, S., Sutopo \& A. Santi, (2009) frekuensi fenotipik sifat-sifat kualitatif ayam kedu dewasa (Fenotype Frequency of The Qualitative Traits at Adult Kedu Chicken). Prosiding Seminar Nasional Kebangkitan Peternakan Fakultas Peternakan . pp. 112.

Johson, L.A., K. F. Weitze., Fiser \& W. M. C. Maxwell. (2000). Storage of Boar Semen. J. Anim. Sci. 62:143-172.

Morell, J.M., A. Johannisson, H. Strutz., A-M. Dalin \& H. Rodriguez-Martinez. (2009) Colloidal centrifugation of stallion semen: changes in sperm motility, velocity and chromatin integrity during storage. Journal Equine Veterinary Science 29:24-32.

Mulyadi, P.M. (2007). Karakteristik Semen ayam Arab, Pelung dan Wareng Tangerang. Skripsi Fakultas Peternakan Institut Pertanian Bogor.

Sartika, T., Sulandari, S., Zein, M. S. A., \& Paryanti, S. (2006). Karakter fenotipe/genetic ekstemal ayam lokal Indonesia. Bahan Laporan Akhir Penelitian Kompetitif Riset Karakterisasi molekuler-LIPI

Sastrodiharjo, S., \& H. Resnawati. (2003). Inseminasi Buatan ayam buras. Jakarta (ID): Penebar Swadaya.

Supriatna, I. (2000). Inseminasi Buatan pada ayam. FKH-IPB. Bogor.

Toelihere, M. R. (1993). Inseminasi Buatan pada Ternak. Angkasa, Bandung. 